fined its attention to more limited objectives and admitted that, even with respect to these, its recommendations were only a starting point.

It is well known that post-war Europe is confronted with a grave timber problem. It is not a matter, as some appear to think, of merely seeking out accessible sources of supply and cutting the forests down. The large excess fellings and destruction committed during the War has led to a serious position in parts of Europe and outside Europe. Excess fellings cutting out more than the annual increment of one or more years-means in the end the disappearance of a forest. Even to supply the well-known needs for timber of large populations we should not be justified in dooming forests which should be maintained in the interests of posterity and often for reasons quite other than timber alone.

For Europe alone it was known that more timber annually is required than pre-war Europe used; yet the soft-wood timber supplies are below the average of the year before 1939. This is delaying reconstruction. Methods of bridging the gap, it was realized, appeared to be not only inadequate but also difficult to achieve ; there was also the fear that repercussions might lead to an even more serious crisis in the future; in other words, overcutting after the drain imposed on the coniferous forests during the War might lead to lasting damage to the surviving European forests. The second alternative appeared equally difficult : a reduction in timber consumption was equally undesirable, since it is in apparent conflict with improvement in housing and living standards which has been adopted as a primary objective by the United Nations Organisation. The Conference approached this matter by dividing it into three parts: (1) short-term problems; (2) longterm problems; and (3) further procedure; and the three chapters of the report deal with the problems in this manner.

The Belgian delegate reported on savings effected by substituting other materials for lumber. A memorandum was submitted by the United Kingdom on economy and the uses of timber, including restrictions and the fixing of maximum sizes in which timber is to be used for joists, rafters, floorboards and so forth. Some of these restricted efforts, it may be said, have not proved very satisfactory, and do not help in reconstruction on the countryside.

A note had been drawn up by the Food and Agriculture Organisation Preparatory Commission on World Food Proposals, and briefly this report stated that the timber situation presents the same problem which has confronted the Commission in regard to several other commodities with, says the report, "the important difference that as food scarcities begin to subside, the world-wide timber shortage is becoming more serious".

It is suggested in the present report that a better organisation for distribution and allocation, by transport and credit facilities, would assist in some degree; the introduction of technical improvements in order to ensure better utilization of available timber supplies would also be valuable.

There is another resolution submitted by the Economic and Social Council of the United Nations, recognizing the seriousness of the present timber shortage in Europe which threatens to delay economic recovery, and this resolution welcomes the initiative taken by the Food and Agriculture Organisation. It is not possible here to deal in detail with all the resolutions and recommendations adopted by the
Conference; but briefly they refer to various details in forest management and to the necessity for dealing with the world-wide shortage of timber in such a manner that serious depredations will not be made on the forests, which would result in their destruction. It is also recommended that proper organisation and proper technical methods should be introduced into the management of forests, and having regard to the long period required for the development of forest resources and for the fulfilment of domestic rational forest policies, it is considered desirable "that the European countries concerned should meet together from time to time to exchange information and views about their problems in the field of medium- and longterm forestry. F.A.O. under its existing mandate is able to call together consultative committees, and it would seem appropriate therefore that F.A.O. should consider providing such a committee on forestry within its framework. It could meet from time to time as might seem necessary in the opinion of F.A.O. and of the governments concerned acting in close consultation." E. P. StebBING

\section{SCIENTIFIC APPROACH TO THE LACE INDUSTRY}

$\mathbf{T}$ its treatment of scientific and technical research and development, the report of the Board of Trade Working Party on the Lace Industry*, of which Miss L. S. Sutherland was chairman and the late Prof. J. M. Gulland a member, follows similar lines to earlier reports from 'working parties' dealing with other textile industries. Like most of the latter, the machine-lace industry grew out of a craft, that of traditional hand-lace, and was not born of scientific research. In addition, it has always been, and still is, essentially a cotton industry, and in its essentials the industry remains the same as in the days of our grandfathers.

Speaking in very broad terms, in the past the lace industry in Britain has shown little interest in research. The total expenditure by individual firms on research appears to be small, and contribution to co-operative research by membership of research institutes such as the British Cotton Industry Research Association was by no means universal although fairly common. In spite of signs of a changing attitude in recent years, the 'working party' attributes many of the present urgent problems of the industry to its failure over a long period to investigate systematically and scientifically the textile, engineering and other aspects of the trade, not least important being those affecting health. One of the strongest recommendations in the report is, in fact, that the newly formed Research Council for the industry should press forward its investigations into a satisfactory substitute for graphite, the use of which as a lubricant for lace machines has given the machine-holding sections the character of a 'dirty trade'.

In characterizing the lace industry as a whole with indifference to research, with neglect of fundamental research and with a marked tendency for whatever research is prosecuted to be sporadic, and noting the absence of research staff and, excejpt in the dressing section, even of scientific staff, the 'working party' frankly recognizes that no industry could achieve

*Board of Trade. Working Party Reports : The Lace Industry. (London: H.M. Stationery Offee, 1947.) 38. 6 d. net. 
products of such technical excellence as lace fabrics without a background of continual inquiry and trial. None the less, it is questionable whether inquiries into the use and handling of difforent yarns have in general been prosecuted with sufficient system to yield their full potential value. Investigations are frequently short-term projects to solve specific production problems, and are shelved when these have been overcome sufficiently for the immediate needs.

Valuable services have indeed been rendered to many firms by the Textile Testing Department, until very recently a part of University College, Nottingham, and by several research associations, but the 'working party' suggests that there are at least four factors restricting the development of research in the industry as a whole. As in the cotton industry, there has been lack of contact between the machine-holders and the machine-builders; the industry is almost entirely lacking in scientifically trained personnel in its higher ranks; the intense individualism of the industry has prevented a united approach to technical and other mutual improvements; and lastly, many machine-holders have taken a narrow view of their functions - to regard their function as limited to processing yarn supplied to them in a finished state with machinery planned and built by others, and to consider in consequence that little or no investigation is required of them other than innovations in design and yarn utilization, and handling.

These factors have to some extent been weakened by experience gained in co-operative research and production during the War, and the formation in January 1944 of a Technical and Research Committee of the Federation of Lace and Embroidery Employers' Associations led in June 1945 to the formation of a Lace Research Council, consisting of the members of the former Committee and the professors of botany (industrial mycology), chemistry, electrical engineering, physies and textiles of the University College of Nottingham. The Federation, however, was not disposed at that stage to establish a research association under the Department of Scientific and Industrial Research, but having guaranteed an income of $£ 2,000$ per annum for a period of three years, the Federation approached the latter Department to obtain Government assistance. As a result of this approach, the Research Council will have at its disposal a total income of $£ 4,500$ per annum during the three-year period and has already appointed as liaison officer in research matters a chemist of long experience of textile processes. The Council has, however, no laboratories and the duties of this solitary scientific officer are in the first place confined to formulating the problems and conditions facing the industry, maintaining contact with research associations and inaugurating investigations under contract at universities, technical colleges and elsewhere, and to the dissemination of information.

That, broadly, is the position which the 'working party' -whose conception and differentiation of research is in line with those detailed in the report of the Cotton Working Party-seeks to meet by what has now come to be the customary prescription of 'working parties', namely, a compulsory levy. It does not, indeed, suggest that a compulsory levy should be made solely for scientific and technical research : it is also intended to cover the financing of economic arid market research, the promotion of overseas sales and the establishment of a design and fashion centre. The 'working party' does not go further than to suggest that the question whether the industry can afford not to inaugurate a fully fledged research association with its own staff, laboratory and workshop should be under constant review. It does not appear, however, to have contemplated any alternative to the usual research association for an industry in which much educational work is imperative before support can be won for research, and utilization of the results of research ensured.

\section{COLOUR PHENOMENA IN THE PERCEPTION OF FINE DETAIL}

TN a recent memoir, "The Visual Perception of Fine Detail", Prof. H. Hartridge has discussed the way in which "the image formed on the retina is clarified and improved before it reaches the higher centres of the brain", and considers in particular the reason why objects in white light are not seen surrounded by the coloured fringes which are certainly produced by the aberrations of the dioptric system of the eye (Phil. Trans. Roy. Soc., B, 232, 519; 1947). To throw light on this question, observations were made of the changes in apparent colour of coloured test objects, in some cases monochromatic stimuli, when their angular size was greatly reduced and when other factors-the brightness of the background, the proximity of other coloured objects, the pupil size, etc.--were modified.

While some of the results will be familiar to readers of Helmholtz ("Physiologische Optik", 2, 128 and 239-41, 3rd Edit.), many new observations are reported, and it is shown how they fit in with the apparent absence of fringes in ordinary vision. After skittling down a number of alternative hypotheses, Prof. Hartridge puts forward his own explanation of the changes in apparent colour. His 'neurological hypothesis' postulates four nervous mechanisms (antichromatic responses) which operate locally in all parts of the fovea and parafovea and the function of which is to control the connexion between photoreceptors and cranial centres. Thus the connexion between medium-wave receptors and the cranial centre for short waves is controlled by the "yellow" mechanism, that between short-wave receptors and their cranial centre by the 'blue' mechanism. The mechanisms may also act together: the 'red' and 'green' mechanisms acting together change colourless vision to reduced (so-called diochromatic) vision, and 'yellow' and 'blue' mechanisms acting together then alter the latter to full colour vision. The neurological hypothesis is not a simple one, and without the answers to several questions, which Prof. Hartridge does not provide, it is difficult to form even a crude picture of the way the mechanisms work. It is not clear, for example, whether they have end-organs of their own or whether they must receive nervous stimuli from the photo-receptors which they are connecting or disconnecting with the cranial centres. More specific assumptions would seem necessary if any quantitative development of the hypothesis is to be possible.

To answer another main question, namely, the reason why at high intensities visual acuity depends so little on the colour of the light, Prof. Hartridge suggests that retinal receptors of each particular type (spectral response) tend to be collected in small clusters. Thus to see fine detail in blue light, the retinal image is brought on to a cluster of 'blue' 